\title{
O SILÊNCIO NO DIREITO ADMINISTRATIVO
}

\author{
HERALDO GARCIA VITTA*
}

\begin{abstract}
a) Introdução - I. A Função Administrativa - 2. A Noção de Ato Administrativo - 3. O Fato Administrativo. A distinção entre Ato e Fato Administrativo - 4. O Silêncio na Administração Pública - B) Conclusões
\end{abstract}

\section{a) Introdução}

As funções estatais básicas, legislar, administrar e julgar, a contar de determinado momento histórico, deixaram de estar nas mãos de uma só pessoa. Criaram-se órgãos do Estado, embora reconhecendo-se a unidade do Poder, cada qual com as atividades determinadas pelo ordenamento, entrelaçadas e coordenadas. Essas atividades foram distribuídas aos órgãos Legislativo, Executivo e Judiciário, por intermédio dos quais o próprio Estado e os administrados passaram a reger sua vida e seus negócios.

Porém, em virtude da complexidade dessas funções, justamente pela coordenação delas, torna-se possível um órgão realizar função de outro; este realizar as daquele, e assim por diante. Vê-se, dessa forma, o intrincado problema de saber-se qual o regime jurídico a aplicar-se na atividade estatal desenvolvida por determinado órgão, pois, evidentemente, o regime jurídico das leis, do ato administrativo e da sentença não são os mesmos, diferem-se entre si, refletindo-se nos conceitos dos objetos e nas consequiências jurídicas estudados pela ciência do Direito.

Muitos autores, talvez a maioria, sobrelevam a existência do silêncio administrativo, como "substituição" da manifestação da vontade estatal. A omissão do Poder Público, em certas hipóteses, acarretaria a equivalência à declaração do Estado, e. assim, ter-se-ia um ato administrativo. No entanto, $o$ ato jurídico, como

* Ex-Promotor de Justiça no Estado de São Paulo, Juiz Federal da $10^{a}$ Vara Cível em Curitiba-PR, Mestrando na PUC-SP, Professor de Direito Administrativo na Faculdades Integradas Curitiba.

R. Dir. Adm..

Rio de Janeiro, 218: 113-138.

out./dez. 1999 
o é o ato administrativo, é uma pronúncia. uma declaração; mas o fato jurídico. como tal, não é declaração, nem pronúncia - ocorre, simplesmente. Daí haver distinção entre eles.

O silêncio, assim, é um ato ou um fato? Quais as consequiências disso? Pode o juiz atribuir ao silêncio determinado efeito, ainda que a lei não o tenha previsto?

Nosso estudo levará em conta tais questões; iniciaremos pela função administrativa, pois o ato administrativo exige sua compreensão, até ubicarmos na distinção entre ato e fato para, finalmente, chegarmos no silêncio da Administração Pública, onde levantaremos alguns problemas para reflexão.

A escolha do tema é proposital. O trabalho não o esgota e permite diversas alternativas e indagações, propicias para análises futuras.

\section{A Função Administrativa}

Antes de ingressarmos no tema propriamente dito, urge verificarmos a função administrativa, na qual o ato jurídico, editado pelo agente público, terá a conotação de ato jurídico-administrativo. Ou seja, apenas no exercício da função administrativa, o agente estatal, ou quem lhe fizer as vezes, expedirá ato administrativo. Logo, o início deve ser a noção da função administrativa", ponto de partida para entendermos bem do ato administrativo.

1) O ilustre jurista alemão Otto Mayer $^{1}$ divide as espécies de atividades estatais em quatro: legislação, justiça, administração e governo.

Segundo o autor, (a) o governo influi em todas as atividades materiais do Estado, corresponde à alta direção do Estado, no sentido de uma boa política e interesse geral. O governo não desce no terreno do Direito. (b) A legislação, por seu turno, possui dois elementos (1) o estabelecimento, pelo poder soberano, de regras gerais e obrigatórias de direito, o qual (2) se manifesta por um corpo representativo. (c) A justiça, de sua vez, é a atividade estatal que busca (1) manter a ordem jurídica, (2) por meio dos tribunais. Envolve a declaração do direito individual, a jurisdição voluntária, as medidas coercitivas por agentes etc. A administração judiciária (gestôes e atos preparatórios à boa marcha da justiça, como conservação de material, nomeação de servidores), porém, não significa manter a ordem jurídica; logo, pertence à administração. (d) A administração tem noção delimitada "negativamente" - faltando um dos elementos da legislação ou da justiça, a atividade será administrativa. A administração exerce-se "sob a autoridade da ordem jurídica".?

$\mathrm{O}$ mestre alemão alude à existência de outras atividades, além das já referidas, as quais não são legislação, justiça ou administração, tais (a) as atividades auxiliares do Direito Constitucional - como a nomeação dos membros do Parlamento, a direção das eleições, etc.; (b) as atividades sob o Direito das Gentes - elaboração dos tratados internacionais, as relaçōes diplomáticas, etc. (c) as ordenanças de

1 "O Direito Administrativo Alemão", Tomo I, p. 3 ss.

2 Logo, ela está sob a ordem jurídica; deve cumprir a lei. 
urgências, poder do príncipe de editá-las, como medidas extraordinárias: e (d) as medidas individuais tomadas sob a forma de lei - como são a concessão, a declaração de utilidade pública. ${ }^{4}$

Portanto, para Otto Mayer, há oito funções exercidas pelo Estado; a Administração é conceituada no sentido negativo, vale dizer, a atividade estatal que não for legislação ou justiça (além das outras já referidas) será administração.

2) $\mathrm{O}$ insigne jurista italiano Renato Alessis ${ }^{5}$ designa Estado como uma organização, isto é, um sistema de normas (ordenamento) e um sistema de poderes', este último tendo as características de "coercibilidade" e "dever" das autoridades públicas. Função estatal, de acordo com o mestre, é o poder estatal dirigido às finalidades coletivas, objeto de um dever jurídico. ${ }^{7}$

Para Renato Alessi, (a) legislação é a emanação de atos primários (inovação no mundo jurídico e primária, isto é, com efeito direto e imediato do Poder Soberano ${ }^{8}$ ); (b) a jurisdição é a emanação de atos subsidiários dos atos primários; é (c) a administração, a emanação de atos complementares dos atos primários, numa situação de superioridade (potestade). ${ }^{9}$

Logo, a administração é atividade concreta, ação positiva para a seguridade, o progresso e o bem-estar do povo. Em suma: é ação direta.

O autor denomina "função administrativa", no sentido objetivo, material, a realização de fins concretos do Estado, a emanação de atos de produção complementares, como parte na relação. Com efeito, enquanto na legislação e na jurisdição o Estado está acima e à margem das relações, na administração, ao contrário, o Estado é parte, é sujeito da relação, conquanto o seja de maneira superior (potestade estatal). ${ }^{10}$

3 Como resquício dessas medidas "excepcionais" do príncipe, pensamos enquadráveis as medidas provisórias, na prática e em face das decisōes judiciais, não permitindo a verificação de seus pressupostos, em flagrante contradição com o Texto Constitucional, cujo artigo 62 estipula os requisitos de sua emanação, evidentemente sindicáveis pelo Poder Judiciário.

4 No Brasil, aliás, há atos materialmente (substancialmente) administrativos editados pelo Poder Legislativo, como são as leis que decretam a desapropriação, concedem isençōes etc., os quais estão sujeitos à impetraçāo de mandado de segurança por causa de seus efeitos concretos e imediatos.

5 "Sistema Istituzionale del Diritto Amministrativo Italiano", p. I e ss.

6 sistema...

7 Como se vê, o exercício da função estatal é um "dever" das autoridades públicas; o termo deve vir antes do "poder", expressão esta utilizada apenas para ultimar aquela. Seria muito bom se nossas autoridades notassem a nítida e importante diferença - não se cuida de mero "jogo de palavras", mas de importante colocação conceitual: a função estatal é um "dever-poder" e não "poder-dever". 8 Assim, apenas a lei pode inovar a ordem jurídica. Nāo concebemos possa o ato administrativo, sobretudo o regulamento, que é, de regra, geral abstrato e impessoal, realizar esta tarefa.

9 Decorrente, a nosso ver, da supremacia do interesse público sobre o do particular, por meio do qual o Estado age de forma unilateral, numa posição sobranceira em relaçāo aos indivíduos componentes do Estado.

10 Para o autor, a Administração Pública, hoje, deve ser conceituada mediante conciliação da noção subjetiva e objetiva: a) sentido objetivo-desenvolvimento da "função administrativa" por partes das "autoridades" pertencentes à ordem administrativa; b) sentido subjetivo-conjunto de "autori- 
Há, ainda. a "função política ou de governo". a atividade de ordem superior correspondendo à direção suprema e geral do Estado, para determinar os fins da ação estatal, buscando a unidade de orientação (unidade de soberania) - tais os tratados, a declaração de guerra, a convocação e dissolução das Câmaras etc.

Os órgãos estatais realizam funções características e normais (Poder Legislativo-função legislativa; Poder Jurisdicional, função jurisdicional; Poder Executivo, função executiva - no âmbito desta, a "função administrativa"). Mas não têm competência absoluta, e sim mera "coordenação de funções". De outro lado, os órgãos estatais têm competência excepcional: (a) a potestade regulamentar, as quais são autênticas normas jurídicas, atividade materialmente legislativa dos órgãos administrativos; ${ }^{11}$ (b) funções jurisdicionais - como as do Conselho de Estado e do Tribunal de Contas. ${ }^{12}$

De importância notável, trazida por Renato Alessi, as relações existentes entre a função administrativa e a função legislativa: a primeira está subordinada à segunda (princípio da legalidade), quer (a) no sentido negativo (são as proibições, quanto às finalidades a alcançar, os meios e as formas a seguir), ou (b) no sentido positivo (a lei pode vincular a atividade administrativa nas finalidades, meios e formas). $E$ conclui: a administração somente pode fazer aquilo que a lei permite. ${ }^{13}$

3) O professor argentino Gordillo ${ }^{14}$, critica o conceito negativo de Administração (é a função que não se inclui na legislação e jurisdição) ${ }^{15}$, e o conceito positivo. quer o orgânico ou formal (é o ato realizado por órgão administrativo, que é dependente e tem hierarquia, ao contrário do jurisdicional, o qual é independente e sem hierarquia; e do órgão legislativo, que tem índole constitucional) ${ }^{16}$, ou o material ou substancial (os atos da função administrativa são manifestações concretas, os da

dades" pertencentes à ordem administrativa, enquanto desenvolvam uma função "materialmente administrativa", compreendendo, por outro lado, na "funçāo administrativa", a emanação de "regulamentos administrativos". (ob. cit., p. 12).

11 No Brasil, o regulamento só pode dar cumprimento à lei anterior editada. É subordinado à lei, quanto ao conteúdo e à forma (art. 84, IV , CF/88). Aliás, na Itália, Renato Alessi aduz ser os regulamentos administrativos equiparados às atividades administrativas: são misto de legislaçāo $\mathrm{e}$ administração; e a tutela, a reaçāo, em relaçāo aos administrados, é idêntica. (Ibidem)

12 As decisões dos Tribunais de Contas, no Brasil, segundo pensamos, estão submetidos ao crivo do Poder Judiciário, em face do artigo 5", XXXV: “- a lei não excluirá da apreciação do Poder Judiciário lesão ou ameaça a direito". Trata-se de decisōes meramente administrativas, embora louváveis, as quais podem ser contrastadas perante o Poder Judiciário, não só quanto ao aspecto formal (legalidade), mas, sobretudo, quanto ao seu aspecto substancial, ou, para utilizarmos da expressão corrente, no seu mérito.

$13 \mathrm{E}$, não, frisamos, o que a lei não proßbe

14 "Tratado de Derecho Administrativo". Tomo I, Cap. VII, p. 1 e ss.

$15 \mathrm{O}$ autor diz ser insuficiente, porque há atos que não são legislação $\mathrm{e}$ jurisdição, e há dúvidas de que atos se trata.

16 Segundo o autor, este critério é errôneo, pois os órgãos legislativo e jurisdicionais também realizam funçāo administrativa. 
função legislativa e a jurisdicional são abstratas). ${ }^{17}$ Suas conclusões são interessantes. pois. no sentido material: (a) o órgão administrativo realiza funçōes: administrativas, legislativas (regulamentos) e jurisdicionais (julgamentos no recurso hierárquico); (b) o órgão jurisdicional realizada funções: jurisdicionais e administrativas; (c) o órgão legislativo realiza funções: legislativas e administrativas. ${ }^{18}$

Logo, há atos materialmente legislativos que são organicamente administrativos, como os regulamentos; atos materialmente administrativos que são organicamente legislativos (investigação, pedidos de informações, autorização); atos materialmente administrativos que são organicamente legislativos (nomeação e remoção dos servidores da justiça); atos materialmente jurisdicionais que são organicamente administrativos (quando o Poder Executivo decide um recurso hierárquico).

Conlui o mestre da necessidade de utilizar-se de critério misto para conceituar cada uma das funções, combinando elementos de um e de outro tipo. ${ }^{19}$

No sentido orgânico-material, então, o autor passa a conceituar cada uma das funções estatais. (a) A função legislativa é composta de atos materialmente legislativo $^{20}$ e realizados por órgão legislativo. O Poder Executivo, ao editar regulamentos, não exerce função legislativa, pois aqueles têm gradação hierárquica com a lei ${ }^{21}$, não podendo contradizê-la. Assim, os órgãos administrativos não exercem função legislativa. O Poder Judicial, mediante os regimentos internos não legisla, porquanto têm graduação hierárquica com a lei e não podem contradizê-la - o regime jurídico não é função legislativa. O mesmo ocorre com os acórdãos. Por conseguinte, o Judiciário não exerce função legislativa.

A conclusão, quanto à função legislativa, é: realizada apenas pelo Poder Legislativo, sendo elementos dessa função: o material ou objetivo (normas gerais) ${ }^{22}$, e o orgânico ou subjetivo (apenas pelo Poder Legislativo).

(b) A função jurisdicional, segundo o autor, no conceito orgânico-material ${ }^{23}$, é a realizada apenas pelo Poder Judiciário, pois o Legislativo quando decide remover

17 Para o autor, a funçāo administrativa nem sempre se limita a manifestaçōes concretas da vontade.

18 É importante ressaltarmos, no ponto, que os três órgāos estatais realizam funções administrativas.

19 Estas considerações também foram feitas por Renato Alessi.

20 Podemos advertir as situaçōes anômalas, porém não impossíveis, nas quais o Legislativo edita normas individualizantes, como notou Otto Mayer, quais a decretaçāo de utilidade pública, a concessão de serviços etc. Logo, o ato é materialmente administrativo, editado por órgāo legislativo, e o regime jurídico é o da função legislativa, e não o da funçāo administrativa.

21 É o nosso caso, nos termos do artigo 84, IV, da Constituição, segundo o qual compete ao Presidente da República: "sancionar, promulgar e fazer publicar as leis, bem como expedir decretos e regulamentos para sua fiel execução." Na verdade, há outros atos gerais, abstratos e impessoais, além dos regulamentos, igualmente editados pelos órgãos administrativos, como as circulares e instruçōes, os quais têm o regime jurídico-administrativo, embora possuam as qualidade indicadas, como as leis as possuem.

22 Já constatamos a existência de atos individuais editados pelo Poder Legislativo, sob a forma de lei. como adverte Otto Mayer.

23 No conceito objetivo. ou seja, ante o conteúdo da função, a função jurisdicional é a decisão com força de verdade legal entre as partes. 
determinado servidor de sua função política atua no regime jurídico-administrativo; e o Executivo. ao decidir questões disciplinares dos servidores ${ }^{24}$ não atua como órgão imparcial ou independente ${ }^{25}$ e a decisão não é definitiva ${ }^{2 \hbar}$.

Portanto, são elementos da função jurisdicional: material ou objetivo (decisão com força de verdade legal entre as partes), orgânico ou subjetivo (praticada pelos juízes, que são órgãos independentes e imparciais). ${ }^{27}$

(c) Agustín Gordillo, especificamente à função administrativa, ensina-nos cuidar-se de conceito cujo conteúdo é impreciso, indefinido, mas, de qualquer forma, realizada pelos Poderes Legislativo e Judiciário; logo, sob o regime jurídico da atividade administrativa. E arremata: "Função administrativa é toda atividade que realizam os órgãos administrativos, a atividade que realizam os órgãos legislativos e jurisdicionais, excluídos, respectivamente, os fatos e atos materialmente legislativos e jurisdicionais. ${ }^{28}$

4) O ínclito professor da PUC-SP, Celso Antônio Bandeira de Mello, por seu turno, ao realizar importantíssima decomposição do ato administrativo, mediante classificação de seus elementos e de seus pressupostos, ao mencionar estes, no tocante à existência do ato, incluiu além do objeto (o qual, diga-se difere do conteúdo do ato) a "pertinência à função administrativa" ${ }^{29}$, vale dizer, o ato administrativo é o ato jurídico emanado no exercício da função administrativa, definido esta como "a função estatal, exercida normalmente pelo Poder Executivo e seus sujeitos auxiliares e atipicamente por órgãos de outros Poderes, sempre na conformidade de um regime hierárquico, e que, tal como resulta do sistema constitucional brasileiro, caracteriza-se juridicamente pelo fato de ser desempenhada mediante comportamentos infralegais ou, excepcionalmente, infraconstitucionais vinculados, submissos todos a controle de legalidade pelo Poder Judiciário." ${ }^{30}$

5) O não menos notável professor Oswaldo Aranha Bandeira de Mello ${ }^{31}$ acentua o Estado como organização jurídica de um povo em dado território, sob um poder supremo, para a realização do bem comum dos seus membros, e pressupõe: (a) o Estado-poder, o qual diz respeito à sua própria organização jurídica, como meio para a consecução do fim do Estado-sociedade, seja nas relações externas (com outros Estados), seja nas relações internas (com sua própria estrutura política); (b) o Esta-

24 Acrescentamos nós, ao decidir quaisquer questões dos particulares.

25 Ao contrário do Poder Judiciário.

26 Podemos acrescentar, exceto nas naçōes nas quais se têm o contencioso administrativo.

27 De certo modo, a colocação coincide com a de Renato Alessi. ao asseverar acerca da função jurisdicional: no caso, o Estado atua acima e à margem das relaçōes, assim como na função legislativa, o que não ocorre na função executiva, na qual o Estado é sujeito das relações. apesar de estar numa posição de superioridade. (ob. cit., pp 7-8)

28 ob. cit., p. 42 .

29 Curso de Direito Administrativo", p. 279.

30 Idem, rodapé 22.

3 "Princípios Gerais de Direito Administrativo", vol. II, p. 13 e ss. 
do-sociedade, referindo-se à organização jurídica da vida social das pessoas. tanto nas recíprocas relações, envolvidos mediatamente pela autoridade estatal, como nas relações imediatas dessas pessoas, isoladamente ou em sociedades menores por eles constituídas, com o Estado-poder e vice-versa.

De acordo com o autor, a (a) Ação Normativa do Estado-Poder corresponde à sanção de leis jurídicas, isto é, de normas de conduta, gerais, abstratas e impessoais, que inovam originariamente na ordem jurídica ${ }^{32}$; ordenação normativa da conduta dos componentes do Estado-sociedade, em caráter coercitivo. Mas a ação normativa legislativa é "completada" por outras normas jurídicas, que dispõem sobre a sua "execução": são os regulamentos e as instruções. A (b) Ação Executiva do Estado-poder é a realização, em concreto, de todas as normas jurídicas, através de (1) atos jurídicos, verdadeira manifestação de vontade, para a produção de efeitos na ordem do direito, de efetivação da ação pública legislativa; (2) atos materiais, pressupostos ou complementos diretos dos atos jurídicos; ou atos materiais com certa autonomia, de oferecimento de comodidade dos particulares, efetuando obras públicas ou executando serviços públicos. ${ }^{33}$ A (c) Ação Judicial do Estado-poder é a ação judicante, através da qual o Estado-poder aplica a norma jurídica disposta pela ação legislativa aos casos concretos. Por ela, se visa, imediatamente, assegurar o direito constante da norma; porém, de modo indireto, por meio das partes litigantes, em controvérsia.

Para o autor, são órgãos do Estado-poder, segundo conceito material dos atos jurídicos, os Poderes Legislativo, Executivo e o Judiciário. No entanto, não se podem confundir os órgãos do Estado-poder com as suas funções, mesmo com as ações que o especificam, pois há atividades:

(1) de natureza executiva, realizadas pelo (a) Poder Legislativo, como a aprovação do orçamento, autorizando a despesa e receita do Estado-poder, a aprovação de normas de candidatos apresentados pelo Executivo para serem por ele nomeados para altos cargos; (b) Poder Judiciário, como a jurisdição voluntária, na qual não há resolução de qualquer controvérsia jurídica - inventário de bens a serem partilhados, a arrecadação e a administração de bens de ausentes etc ${ }^{34}$; bem como os atos judiciários nos processos contenciosos, por exemplo: "Preparados, voltem-se conclusos os autos para sentença".

(2) de natureza jurisdicional, realizadas pelo (a) Poder Legislativo, o "impeachment", que são juízos políticos, nos quais se julga os titulares dos órgãos dos Poderes Executivo e Judiciário, por crimes funcionais ou má conduta no exercício de suas

32 Logo, apenas a lei pode inovar no mundo jurídico, como acentua Alessi.

33 Devemos ressaltar, nos termos do ensinamento do autor: a ação legislativa estabelece o escopo e as balizas da ação executiva, mais ou menos rígidas; ela se move conforme a maior ou menor liberdade que lhe é conferida. (ob. cit., p. 19). É o princípio da legalidade, insculpido entre nós nos artigos 5", II e 37, "caput", do Texto Constitucional.

34 Tivemos oportunidade de ver que Otto Mayer inclui a jurisdiçāo voluntária como atividade judicial. 
atividades ${ }^{35}$ : (b) Poder Executivo, ao decidir sobre pretensōes das partes. administrativamente. na defesa dos seus direitos, frente ao Estado-Poder. e ao punir. disciplinarmente, seus próprios agentes.

(3) de natureza legislativa, realizadas pelo (a) Poder Executivo, ao participar na elaboração da lei, e na prescrição de atos normativos, como os regulamentos e as instruções, impondo regras de conduta aos particulares e aos seus agentes. ${ }^{36}$; (b) Poder Judiciário, por meio dos regimentos normativos, para regular a marcha dos seus respectivos trabalhos. ${ }^{37}$

Contrariando a doutrina majoritária, propõe duas faculdades distintas, dois poderes fundamentais: o político, de integração da ordem jurídica, mediante o seu estabelecimento e sua atuação; e o jurídico, de reintegração dessa ordem jurídica.

A ação legislativa e a executiva do Estado-poder, segundo o autor, são dois momentos sucessivos de uma mesma função. Englobam a criação de novas utilidades sociais, por meio de normas jurídicas, que as dispõem, ou atos jurídicos, que as concretizam, e atos materiais complementares. Logo, a função administrativa é deliberação normativa e sua execução. Ou seja, a função administrativa é criação de utilidade pública, através de ação legislativa e executiva, efetuada de modo imediato e direto.

A ação judicial tem preocupação de manter a ordem jurídica em vigor, assegurando o direito vigente; o objeto é o próprio direito, é a sua razão de ser.

Os Poderes Legislativo e Executivo são distintos, mas harmônicos, pois constituem estruturas orgânicas autônomas que se entrosam na sua atuação; são dois sistemas orgânicos autônomos, porém do mesmo poder, o Político. O Judiciário é independente delas, forma um sistema a parte, pela própria natureza do seu objeto, e participante de outro poder, o Jurídico.

Por conseguinte, o autor exclui do Direito Administrativo qualquer função jurisdicional, isto é, de dizer o direito das partes em controvérsia, mesmo quando uma delas seja o Estado-poder.

Quanto aos atos de governo (relações externas: diplomáticas, guerras, tratados; relações com outros poderes do Estado: a iniciativa de projeto de lei, a sanção ou veto de lei, a convocação extraordinária do Parlamento, a nomeação de Ministros de Estado; relativos à ordem interna: expulsão de estrangeiros, a anistia, a graça) devem enquadrar-se num ramo do direito: no Direito Constitucional, por exemplo, os pertinentes às relações dos outros poderes, enquanto organização do regime político; e no Direito Administrativo, todos os demais; assim, os atos jurídicos de

35 Vimos que, para Gordillo, não se cuida de atividade jurisdicional mas atividade administrativa, sob regime jurídico de Direito Administrativo.

36 Para Gordillo, o Executivo não realiza função legislativa; seus atos estāo submetidos ao regime jurídico-administrativo.

37 O mesmo Gordillo entende não haver, na elaboração dos regimentos, regime jurídico da função legislativa. 
declarar guerra ou o estado de sítio. ou de firmar tratados com outras potências. bem como de participar na ação legislativa do Estado.

$\mathrm{O}$ autor enfatiza a possibilidade de os atos de governo serem apreciados pelo Poder Judiciário, se ferirem direitos subjetivos das pessoas, ou desconhecerem a ordem jurídica normativa vigente. ${ }^{38}$

6) Para o conceituado jurista francês Francis Paul Benoît, há o Estado-Nação e o Estado-Coletividade. O primeiro corresponde à emissão de normas jurídicas primárias (constituição, leis, decretos, neste último caso, quando não estiver subordinado à lei), tendo controle meramente político; e o segundo, submetido ao regime do Direito Administrativo, têm missões variadas (prestação de serviços aos habitantes, a polícia, a gestão de domínio, as operações materiais), cujo controle é jurídico. Exalta, a subordinação do Estado-Coletividade às normas e às diretrizes do EstadoNação.

Conforme o autor, há três regras pelas quais se deva analisar as funções estatais:

a) distinção da arte da ciência. No caso, a visão artística das funções, causada por conta da separação de poderes difundida por Montesquieu, deve ceder à verificação das tarefas, dos regimes e dos órgãos para chegar-se à noção de função. Esta deve exprimir a realidade do direito positivo;

b) a definição científica das funções deve exprimir a complexidade da realidade jurídica. As missões consideradas não devem dissociar-se do regime conforme o qual elas são assumidas pelo órgão o qual está investido: Enquanto missões são tarefas definidas por seu conteúdo (fazer as leis, manter a ordem na rua) - vale dizer, apenas por seu objeto, independentemente do problema do regime e da atribuição a um órgão - , função é um conjunto homogêneo de missões com um mesmo regime, atribuído a um órgão determinado;

c) a função não pode exprimir que a realidade de um momento; não há valor absoluto. Por exemplo, na monarquia havia somente a função governamental, incluía a missão de legislar.

Essas considerações foram feitas para podermos constatar o quanto torna-se complicada a questão de definirmos a função administrativa. Seu conceito é variável, indefinido, e depende da ordem jurídica de cada país. As tarefas determinadas pelo ordenamento, em vista de certo órgão, segundo o mesmo regime jurídico, constitui, como realçou Benoît, a função. Ocorre não haver unanimidade quanto a saber se tais ou quais missões têm este ou aquele regime jurídico, ou se deve enquadrar-se nesta ou naquela função. Cada autor classifica as funções estatais de acordo com

38 Celso Antônio Bandeira de Mello, quanto aos atos de governo assim se expressa: "Pelo quanto se disse, entretanto - já se vê - , atribuímos à noção de ato político ou de governo relevância totalmente diversa da que the é conferida pela doutrina européia. Esta os concebe para efeitos de qualificá-los como atos insuscetíveis de controle jurisdicional. entendimento que repelimos de modo absoluto e que não se coaduna com o Texto Constitucional brasileiro, notadamente com o art. 5, XXXV." (ob. cit., p. 271). Assiste razão ao preclaro professor, pois tais atos podem ferir direitos subjetivos das pessoas, ou não observar as normas vigentes, quanto ao conteúdo ou à forma, sobretudo em face da própria norma constitucional, a qual poderá trazer pressupostos ou requisitos para a edição de determinado ato, evidentemente sindicável pelo juiz. 
critérios de utilidade e praticidade. Para um. determinado fato torna-se importante ao enquadramento no sistema. enquanto outro entende o mesmo fato não imprescindível à classificação proposta.

De toda forma, a função administrativa, em face das colocações feitas pelos autores citados, comporta algumas conclusões: é a realizada pelo órgão executivo, dependente e hierárquico; logo, baseado numa hierarquia de funções; mas também é a realizada pelos órgãos legislativo e judiciário, quando estes não estejam em suas tarefas normais, suas competências próprias; os atos editados no exercício da função administrativa são sindicáveis pelo órgão judicial, pois não têm caráter de definitividade; tais atos são subordinados à lei.

Vemos assim que o conceito de função administrativa é negativo, no sentido apontado por Otto Mayer, ao menos quanto às tarefas dos órgãos legislativo e judiciário. Parece-nos, de logo, ser correta e perfeitamente clara a definição de função administrativa, fornecida por Celso Antônio Bandeira de Mello, segundo a qual função administrativa "é a função estatal, exercida normalmente pelo Poder Executivo e seus sujeitos auxiliares e atipicamente por órgãos de outros Poderes, sempre na conformidade de um regime hierárquico, e que, tal como resulta do sistema constitucional brasileiro, caracteriza-se juridicamente pelo fato de ser desempenhada mediante comportamentos infralegais ou, excepcionalmente, infraconstitucionais vinculados, submissos todos a controle de legalidade pelo Poder Judiciário." ${ }^{39}$

A importância do conceito de função administrativa, como frisamos, alcança finalidade prática, pois dele se origina o conceito de ato administrativo, na medida em que "a instituição produtora do ato administrativo é a função administrativa."

\section{A Noção de Ato Administrativo}

O ato administrativo é manifestação no exercício da função administrativa. Não importa o órgão que edita o ato; a raiz do ato está objetivamente na função administrativa. Os motivos desta posição permitem, conforme o mestre platino Agustín Gordillo:

“a) eliminar as contradições lógicas entre as noções de função e ato administrativo;

b) fazer a eliminação sem tomar em conta elementos acidentais, mas o regime jurídico;

c) atos do poder judiciário e legislativo referentes à sua organização interna, meios materiais, vida funcional etc., regem-se pelo direito administrativo;

d) é inútil propor a desvinculação entre as noções de ato e função administrativa. por induzir desnecessária complexidade terminológica e conceitual." $\$ 1$

39 Ob. cit., p. 279, rodapé 22 .

40 Augustin Gordillo, ob. cit., Tomo 3, Cap. I. p. 7.

41 Idem, p. 15. 
Se é ressaltada a função administrativa, como fonte produtora do ato administrativo, não é menos importante a noção formal de ato administrativo, sobretudo diante do regime jurídico a ser aplicado ao ato editado pelo órgão. Ensina-nos André de Laubadère:

"No direito positivo, a noção formal de ato administrativo apresente incontestavelmente uma importância capital: um grande número de regras são comuns a todos os atos formalmente administrativos.

Assim, diferente dos atos formalmente legislativos, todos os atos formalmente administrativos estão assujeitados a um controle jurisdicional, e em particular, desde que tenham efeitos de direito são suscetíveis de ser atacados em anulação pela via do recurso por excesso de poder.

Sob diversos pontos de seu regime jurídico, é a noção formal de atos administrativos que fica. Por exemplo, se os regulamentos administrativos têm sido apresentados como atos materialmente legislativos (...), sua natureza de atos formalmente administrativos é suficiente a privá-los do regime jurídico de leis e os submete ao regime de atos administrativos; ao contrário, uma medida individual editada pelo Parlamento, bem que podendo ser apresentado como um ato materialmente administrativo, é beneficiado do regime jurídico de todas as leis formais, e notadamente não pode ser anulada pelo tribunal.

A noção formal de ato administrativo é assim a mais importante pelas consequiências que ele leva sobre o regime jurídico do ato. ${ }^{42}$

A definição de ato administrativo pressupõe classificação prévia de objetos, alguns incluídos no conceito, outros não. Apenas dessa divisão podemos chegar a bom termo e definir o ato administrativo. No entanto, como os autores classificam os objetos de acordo com critério de conveniência ${ }^{43}$, aliás como visto acima, partiremos, de imediato, excluindo os atos não enquadráveis no conceito de ato administrativo, iniciando com a do ilustre professor Celso Antônio Bandeira de Mello.44

42 "En droit positif, la notion formelle de l'acte administratif présente incontestablement una importance capitale: un grand nombre de règles sont communes à tous les actes formellement administratifs. Ainsi, à la différence des actes formellement législatifs, tous les actes formellement administratifs sont assujettis à un contrôle jurisdictionnel, et en particulier, dès lors qu' ils ont des effets de droit, ils sont susceptibles d'être attaqués en annularion par la voie du recours pour excès de pouvoir. Sur plusiers point de leur régime juridique, c'est la notion formelle des actes administratifs qui est à retenir. Par exemple si les réglements administratifs ont été parfois présentés comme des actes matériellement législatifs (infra, sect. 2), leus nature d'actes formellement administratifs suffit à les priver du régime jurídique des lois et à les soumettre au régime des actes administratifs; à l'inverse, una mesure individuelle édictée par le Parlement, bien que pouvant être présentée comme un acte matériellement administratif, béneficie du régime juridique de toutes les lois formelles, et notamment ne peut être annulée par un tribunal." ("Traité de Droit Administratif", Tome I, page 576, tradução do autor, grifos no original)

43 Nesse sentido, Gordillo: "As características comuns que adotamos como critério para o uso de uma palavra de classe são uma questão de conveniência. Nossas classifica ̧̌ōes dependem de nossos interesses e nossa necessidade de reconhecer tanto as semelhanças comı as diferenças entre as coisas. (ob. cit., Tomo I, Cap. I, p.15).

44 Ob. cit., p. 270-1. 
Com efeito, estão excluídos da noção de ato administrativo. embora realizados pela Administração Pública ${ }^{+5}$ : (a) os atos regidos pelo Direito Privado, como a locação de uma casa para nela instalar-se uma repartição pública. O conteúdo e os efeitos não são regidos pelo Direito Privado; apenas as condições de emanação têm regulação pelo Direito Administrativo; (b) os atos materiais, como o ministério de uma aula, uma operação cirúrgica realizada por médico no exercício de sua atividade, a pavimentação de uma rua; (c) os atos políticos ou de governo, praticados com margem de discrição e diretamente em obediência à Constituição, no exercício de função puramente política; e, incluímos nós, d) os contratos administrativos, regidos por regime próprio, específico.

Segundo o mesmo autor, há atos, de outro lado, não praticados pela Administração Pública, mas que "devem ser incluídos entre os atos administrativos, porquanto se submetem à mesma disciplina jurídica..." Como exemplo, os relativos à vida funcional dos servidores do Legislativo e do Judiciário, ou as licitações efetuadas nestes esferas. ${ }^{46}$

O mesmo enfoque podemos atribuir quanto aos efeitos jurídicos do ato. Muitos autores entendem excluir da definição de ato administrativo os atos não possuidores de efeitos jurídicos diretos, imediatos sobre os administrados. De acordo com esse entendimento, apenas os atos geradores de efeitos jurídicos diretos nos administrados seriam verdadeiramente atos administrativos; os demais, como são as informações, não teriam essa característica.

1) Gordillo, de fato, exclui do conceito todos os atos preparatórios (informações, opiniões, projetos etc); não são impugnáveis por recurso administrativo nem judicial, ainda que padeçam de algum vício. $\mathrm{O}$ mesmo ocorre com os que tenham algum efeito jurídico, em união com outros elementos, mas que ainda não o tem: a opinião vinculante ou semivinculante; um ato que deva ser aprovado; um ato que haja sido ditado mas ainda não haja sido notificado.

2) Roberto Dromi, de seu turno, entende ato administrativo toda "declaración unilateral efectuada en el ejercicio de la función administrativa, que produce efectos jurídicos individuales en forma directa". ${ }^{47}$

A maioria dos autores parte da realidade jurídica de seu país. Alhures, há normas legais estabelecendo a situação assinalada: o ato administrativo é sempre uma declaração unilateral, individual com efeitos jurídicos diretos. Assim no Direito argentino, em que as leis de procedimento administrativo das diversas províncias definem o ato administrativo no sentido apontado, no da Alemanha e no da Colômbia.

No Brasil, porém, não há definição legal de ato administrativo. A recente lei federal de procedimento administrativo $(9.784 / 99)$ não realizou essa tarefa, o que dificulta, ainda mais, o tema por aqui.

45 Vemos, desde logo, que a simples noçāo subjetiva de ato ou funçāo administrativa não é suficiente para caracterizar o ato administrativo.

46 Ob. cit., p. 271.

47 "El Acto Administativo", p. 15. O mesmo autor arrola as diversas tendências doutrinárias da definição de ato administrativo. (p. 12-5). 
Pensamos de forma diversa do autores citados: se o ato foi editado no exercício da função administrativa, não se cuidando de mera gestão do patrimônio público, de atos políticos ou de governo, de fatos jurídico-administrativos, e de contratos administrativos, somente pode ser administrativo, na firme certeza de que não se cuida de ato judicial (decisão com força de verdade legal, pondo fim à controvérsia entre as partes) ou de lei (norma abstrata, geral e impessoal, editada pelo Legislativo), na feliz definição no sentido negativo de Otto Mayer.

Isto porque a perfeição do ato não se confunde com sua eficácia; ocorre a primeira quando "esgotadas as fases necessárias à sua produção" ${ }^{48}$; o segundo, quando "está disponível para a produção de seus efeitos próprios..." 49

Ora, uma informação, uma perícia, um parecer, mesmo não vinculativos, existem. Pertencem ao mundo jurídico, tanto constatam fatos, situações, emitem juízos de valor. São manifestações de vontade. Apenas dependem, muitas vezes, de um ato posterior a dar-lhes eficácia, como o ato controlador da autoridade, ou a determinação do fechamento da fábrica, baseada na informação anterior. Parece-nos, então, os referidos atos devem ser incluídos na categoria de atos administrativos, sobretudo para podermos entender os atos administrativos posteriores editados com base neles. Os efeitos jurídicos podem ser diretos ou indiretos, em nada descaracterizando sua natureza jurídica.

3) O professor Oswaldo Aranha Bandeira de Mello, após definir ato administrativo no sentido material ou objetivo ${ }^{50}$ e no sentido orgânico-formal ou subjetivos ${ }^{51}$, explica o abandono, pela doutrina, da distinção entre ato executivo (como manifestação de vontade individual, concreta e pessoal) e ato normativo. Hoje, segundo o autor, há apenas ato administrativo, no sentido de ato executivo, como manifestação de vontade individual, concreta e pessoal. ${ }^{52}$

4) André Gonçalves Pereira ${ }^{53}$, ilustre jurista português, exclui dos atos administrativos os regidos pelo Direito Privado e os contratos administrativos: ato administrativo é ato unilateral e implica o uso de um poder. Para o autor, o regulamento e o ato administrativo têm regimes jurídicos diferentes, que não justificam a construção de um conceito autônomo. São duas diferenças essenciais: o regime de revogação e a impugnação contenciosa.

Quanto ao primeiro, o regulamento pode ser livremente revogado por outro posterior dotado da mesma autoridade formal, não estando submetido ao regime dos

48 Celso Antônio Bandeira de Mello, ob. cit., p. 272.

49 Ibidem.

50 "Manifestação da vontade do Estado, enquanto poder público, individual, concreta e pessoal, na consecução do seu fim, de realizaçāo da utilidade pública, de modo direto e imediato, para produzir efeitos de direito." (ob. cit., p. 463.)

51 "Ato emanado de órgãos encarregados da Administração Pública, compreendendo os integrantes do Poder Executivo, ou mesmo dos outros, desde que tenham a mesma estrutura orgânico-formal daquele, como sejam as secretarias do Legislativo e do Judiciário." (Ibidem)

52 Concordamos plenamente com o autor, quando diz ser preferível a seguinte classificaçāo: gênero - ato administrativo; espécies: ato executivo e ato normativo. (Ibidem)

53 "Erro e llegalidade do Ato Administrativo", Cap. II, p.78 e ss. 
atos concretos. O regulamento é mediato em relação ao administrado. enquanto o ato administrativo é imediato, projetando-se diretamente na esfera jurídica do administrado. Por isso, não pode o ato administrativo constitutivo ser revogado senão em condições determinadas, aliás, restritivas, ao passo que o regulamento pode ser livremente revogado.

No tocante à impugnação contenciosa, se ela é regra no atos concretos, é exceção quanto aos genéricos, só sendo admissível nos regulamento autárquicos. ${ }^{54}$

5) A respeito do primeiro ponto, Celso Antônio Bandeira de Mello enfatiza:

"Compreende-se, então, por que os atos gerais abstratos (como os regulamentos) são sempre revogáveis e por que o problema dos limites específicos ao poder de revogar coloca-se apenas para os atos concretos. É que nos atos gerais e abstratos não se trata de reincidir competência sobre a mesma relação jurídica. Tais atos dispõem para o futuro e não interferem com alguma relação presente. Apanham qualquer relação criada. Logo, não correspondem à reiteração de competência sobre a mesma relação. Consistem no simples exercício normal de uma competência deferida em abstrato e que é manifestada tendo em vista o porvir. Daí sua 'liberdade'." 55

E completa Michel Stassinopoulus:

“Do ponto de vista da revogação, há também uma diferença a notar. Os atos regulamentares são em princípio revogáveis, então que os atos individuais são apenas na medida em que eles não tenham criados direitos. Por outra, a revogação dos atos regulamentares não tem jamais um caráter retroativo - conforme o princípio que não se regulamenta para o passado - enquanto que, num ato individual, sua retirada retroativa é possível." sh

Para nós, contudo, a questão da revogabilidade não é determinador do regime jurídico do ato; o regulamento, embora tenha diferenças no tocante à revogabilidade e à impugnação em relação ao ato concreto, está subordinado à lei, não pode contrariá-la, deve obedecê-la, e é editado na função administrativa, antes estudada. Em uma palavra: o regulamento tem o regime jurídico do Direito Administrativo, pois se cuida de ato editado na função administrativa. Logo, é ato administrativo. Além disso, perante nosso ordenamento jurídico, o regulamento, as instruções etc., atos abstratos e gerais, ${ }^{57}$ podem ser combatidos por intermédio do mandado de

54 No Brasil, ante a possibilidade de mandado de segurança preventivo, a princípio, torna-se possivel açāo judicial contra regulamento, ato normativo.

55 Ob. cit., p. 327 grifos no original.

56 "Du point de vue de la révocation, il y a aussi une différence á noter. Les actes réglementaires sont en principe révocables, alors que les actes individuels ne le sont que dans la mesure oú ils n'ont pas créé de droit. En outre, la révocation des actes réglementaires n'a jamais un caractère rétroactif — selon le principe que 'l'on ne règlemente pas pour le passé' — tandis que, s'aggissant d'un acte individuel illégal, son retrait rétroactif est possible."(???... p, 64 - tradução do autor). É de observar-se, porém, que a revogaçāo, de regra, não tem efeitos retroativos, ao contrário da nulidade do ato, o qual retroage, atingindo o ato em sua origem.

57 Atos concretos são os que dispōem para um único e específico caso, esgotando-se nesta única aplicação. Exemplo: a exoneração de um funcionário; atos abstratos, são os que prevêem reiteradas 
segurança preventivo. na hipótese de ameaça a direito do particular. No ponto, o regime de impugnação judicial aproxima-se daquele do ato administrativo concreto.

Estamos inclinados, assim, a incluir na categoria de atos administrativos os atos abstratos e gerais, bem aqueles, não incluídos nestes, que não possuam efeitos jurídicos diretos.

Diante das considerações feitas, podemos conceituar ato administrativo: "é toda declaração unilateral do Estado, ou de quem lhe faça as vezes, editada no exercício da função administrativa, em complemento da lei, de efeitos jurídicos diretos ou indiretos, concretos ou abstratos, gerais ou individuais, submissa a controle pelo Poder Judiciário".

Conforme veremos a seguir, esta conceituação, baseada na declaração do Estado, tem reflexos importantes na teoria do silêncio da Administração. Antes, porém, devemos distinguir o ato do fato administrativo. É o que faremos.

\section{3. $O$ Fato Administrativo. A distinção entre Ato e Fato Administrativo}

Gordillo mostra-nos a distinção entre atos e fatos; segundo ele, no exercício da função administrativa, há quatro grandes setores da atividade administrativa: (a) atos não jurídicos - são decisões da administração que não produzem efeito jurídico algum. O professor decide explicar um tema antes que outro; (b) atos jurídicos são as decisões ou declarações que produzem efeito jurídico, isto é, produzem o nascimento, a modificação ou extinção de um direito ou um dever. A decisão de designar uma pessoa a um cargo; () fatos não jurídicos - são todas as atuações materiais da administração que não produzem um efeito jurídico direto. $O$ professor de sua classe caminha; (d) fatos jurídicos - a posse de uma coisa por determinado tempo, é um fato que produz efeito jurídico, a aquisição por prescrição; o agente de polícia que detém pessoa sem decisão prévia, produz efeitos jurídicos: nascimento de uma responsabilidade para a administração, direito de indenização. ${ }^{58}$

Vamos nos valer, igualmente, da lição do professor Celso Antônio Bandeira de Mello, para bem delinearmos a distinção entre o fato e o ato administrativo, na medida em que dessa diferenciação resultam importantes conclusões quanto à omissão do Poder Público.

Ensina o mestre:

e infindas aplicações, as quais se repetem cada vez que ocorra a reprodução da hipótese neles prevista, alcançando um número indeterminado e indeterminável de destinatários. Exemplo: o regulamento; atos individuais sāo os que têm por destinatário sujeito ou sujeitos especificamente determinados. Exemplos: nomeação de dado funcionário; a nomeação, em uma única lista, de diversos sujeitos especificados; atos gerais, sāo os que têm por destinatários uma categoria de sujeitos inespecificados, pois colhidos em razão de se incluírem em uma situaçāo determinada ou em uma classe de pessoas. Exemplo: um edital de concurso público. (Cf. Celso Antônio Bandeira de Mello, ob. cit., p. 302).

58 ob. cit. Tomo III, Cap. III-3 
"O ato administrativo é um ato jurídico, pois se trata de uma declaração que produz efeitos jurídicos. Sendo ato jurídico, aloca-se dentro do gênero fato jurídico. Este se define como: qualquer acontecimento a que o Direito imputa e enquanto imputa efeitos jurídicos. O fato jurídico, portanto, pode ser um evento material ou uma conduta humana, voluntária ou involuntária, preordenada ou não a interferir na ordem juridica. Basta que o sistema normativo lhe atribua efeitos de direito para qualificar-se como um fato jurídico." 59

Cuidando da manifestação exterior da vontade da administração nos atos administrativos, dizem "Hauriou et de Bezin":

"É preciso reter, é o caractere exterior dessa declaração; toda vontade administrativa é necessariamente exteriorizada; é uma precaução elementar para distinguir, no agente, as vontades que ele exprime em nome da administração, daquelas que ele poderia ter por sua conta; as vontades administrativas devem ser formuladas exteriormente pelo agente, no exercício de suas funções. A gente pode mesmo sustentar que a forma escrita é exigida para as declarações, de vontade expressa da administração, e que esta exigência é uma precaução natural." (6)

Apenas advertimos de que há atos jurídicos que não são necessariamente comportamentos humanos voluntários. É o caso dos parquímetros que expedem multas, uma vez excedido o prazo do estacionamento. É que "pode haver atos administrativos que não são produzidos por homens. Não se pode, de outro lado, falar em uma vontade da máquina que os expede" ${ }^{\prime 1}$

Em outras palavras, o ato jurídico é exteriorização do pensamento; um processo intelectual. Ao contrário, o fato jurídico é ato material, e bastas vezes, depende do primeiro para ocorrer. Realmente, Celso Antônio Bandeira de Mello enfatiza:

"A nosso ver a solução é a seguinte. Atos jurídicos são declarações, vale dizer, são enunciados; são 'falas' prescritivas. $O$ ato jurídico é uma pronúncia sobre certa coisa ou situação, dizendo como ela deverá ser. Fatos jurídicos não são declarações; portanto, não são prescrições. Não são falas, não pronunciam coisa alguma. $O$ fato não diz nada. Apenas ocorre. A lei é que fala sobre ele. Donde a distinção entre ato jurídico e fato jurídico é simplicíssima." 62

59 ob. cit., p. 265.

60 Ce qu'il faut retenir, c'est le caractere exterieur de cette déclaration; toute volonté administrative est nécessairement exteriorisée; c'est unan precantion élémentaire pour distinguer, chez l'agente les volontés qu'il exprime au nom de l'administration, de celles qui 'il pourrait avoir pour son compte; les volontés administratives doivent être formulées extérieurement par l'agent dans l'exercicie de ses fonctions. On peut même soutenir que la forme écrite est exigée pour les déclarations, de volonté expresse de l'administration, et que cette éxigence est une précaution naturelle." ("La déclaration de volonté dans le droit administratif français", "in" Revue trimestrielle de droit civil, 1903. p. 549. "apud" Themístocles Brandāo Cavalcanti, "Tratado de Direito Administrativo", vol. 1. p. 203, traduçāo do autor).

61 Cf. Tomás Hutchinson, "La actividade administrativa, 1 máquina y el Derecho Administrativo", in RDP 55-56/37-45, notadamente pp. 41 a 43, "apud" Celso Antônio Bandeira de Mello ob. cit., p. 267.

62 ob. cit., p. 268. 
Os fatos jurídicos podem ser simples ou complexos, segundo se realizam por um simples evento, ou exigem para a sua integração uma multiplicidade de fatos. $O$ nascimento, a maioridade, o parentesco, a ocupação, são fatos simples; já o usucapião, que depende de diversos elementos sucessivos é um fato complexo. ${ }^{63}$

Enquanto atos são decisões, declarações dirigidas ao intelecto dos administrados, abstratamente, através da palavra oral ou escrita, ou de signos com conteúdo convencional ou ideográfico (gesto do guarda do trânsito, os sinais de trânsito); fatos são atuações materiais, operações técnicas realizadas no exercício da função administrativa. A "decisão declarada" se dá a conhecer às demais pessoas por meio de "fatos ou dados" que têm significado simbólico: a decisão de permitir atravessar a rua surgirá de uma expressão verbal ou escrita, ou de um signo convencional de trânsito, a decisão de destruir surgirá de uma cartaz etc.; a "decisão executada" se dá a conhecer aos demais indivíduos através dos "fatos reais" que transmitem a idéia respectiva: a decisão de liberar o trânsito de veículos advém da dedução de que nada impede de transitar; a decisão de destruir se infere de que a coisa está sendo destruída. ${ }^{54}$

O discrímen deve ser feito pois (a) os atos administrativos podem ser anulados e revogados; fatos administrativos não são nem anuláveis, nem revogáveis; (b) atos administrativos gozam de presunção de legitimidade; fatos administrativos não; () o tema da vontade interessa nos atos administrativos discricionários, isto é, naqueles em cuja prática a Administração desfruta de certa margem de liberdade; nos fatos administrativos nem se poderia propô- $10^{65}$; (d) os atos administrativos são impugnáveis mediante recursos administrativos e judiciais; os fatos em princípio não são suscetíveis de impugnação, porque não traduz explicitamente a vontade do Estado — há necessidade de interposição de reclamações prévia, pedidos etc. Transcorrido determinado prazo sem que administração se pronuncie, se produz a denegação tácita pelo silêncio administrativo. ${ }^{\hbar \hbar}$

Logo, se ato administrativo é declaração do Estado ou de quem lhe faça as vezes, certamente o silêncio da administração, o qual não se confunde aquela, não é ato; é apenas um fato jurídico-administrativo, portanto, com conseqüências jurídicas atribuídas pelo Direito.

\section{O Silêncio na Administração Pública}

1) André Gonçalves Pereira acentua a função política da teoria do ato administrativo, que teria sido a de estabelecer para o administrado um sistema de garantias de respeito pelo princípio da legalidade por parte da Administração.

63 Themístocles B. Cavalcanti, ob. cit., p. 196.

64 Agustín Gordillo, ob. cit., Tomo III, Cap. III-19.

65 Celso Antônio Bandeira de Mello, ob. cit., p. 268 - grifo no original.

66

Agustín Gordillo, ob. cit., Tomo III, Cap. III-4. 
O mesmo doutrinador português distingue ato tácito do ato implícito. Este resulta de uma conduta destinada a fim diversos, inferindo-se sem possibilidade de dúvida dos "facta concludentia". O autor não se opõe ao ato administrativo implícito, o qual só poderá valer nos caos em que a lei não exija qualquer requisito formal. Por exemplo, num pedido de concessão - se a autoridade concede o mesmo serviço público, por hipótese pedido, a outra pessoa em regime de exclusividade, necessariamente se infere que indefere o primeiro pedido.

$\mathrm{O}$ ato tácito, por sua vez, pode ser (a) interno, quando resulta da omissão de órgão administrativo controlador em manifestar tempestivamente sua aquiescência ou desacordo em relação a ato de outro órgão que deva ser objeto de seu controle. Se não o fizer em determinado prazo, a lei o considera aprovado; e (b) externo, resultantes da omissão administrativa em apreciar, em dado tempo legalmente prefixado, uma pretensão do administrado. Não o fazendo, considera-se rejeitada a pretensão que lhe fora submetida.

Porém, o ilustre autor nega sejam os atos tácitos atos administrativos, sustentando que, no caso dos atos tácitos internos ocorre uma restrição temporal à competência controladora; transcorrida "in albis" a dilação legalmente prevista, a competência controladora não mais pode ser exercida e o ato controlado torna-se eficaz "ope legis". No caso dos atos tácitos externos, há permissão legal para que o interessado passe diretamente às vias contenciosas, com prescindência do ato administrativo denegatório. ${ }^{67}$

$\mathrm{Na}$ verdade, a lei, em determinadas circunstâncias, manda interpretar para certos efeitos a passividade ou silêncio de um órgão administrativo, como significado de deferimento ou indeferimento do pedido. Decorrido o prazo fixado, a lei tira do silêncio a conclusão de que ele significou assentimento, aprovação ou indeferimento.

No Direito português, conforme informa Marcelo Caetano ${ }^{68}$, a regra é a de que o silêncio equivale a indeferimento. Excepcionalmente, a lei manda interpretar o silêncio como significado de aprovação. Segundo este autor, para que o silêncio origine um ato administrativo é necessário:

“ $1^{\mathrm{Q}}$ que o órgão administrativo seja solicitado a pronunciar-se num caso concreto;

$2^{\underline{0}}$ que esse órgão tenha o dever legal de resolver em certo prazo o caso apresentado, mediante a prática do acto definitivo, o que quer dizer que o poder de decidir deve ser vinculado quanto à oportunidade de exercício;

$3^{\circ}$ Que a lei atribua à abstenção de resolução dentro do prazo legal um significado determinado." 69

67 Ob. cit., O autor português Marcelo Caetano nega o entendimento de André Gonçalves Pereira, sob o argumento de que existem atos tácitos (Cf. Manual de Direito Administrativo, p. 434).

68 Idem, p. 432.

69 Idem, p. 433. 
2) No Direito francês, princípios gerais não escritos devem ser considerados como suscetíveis de ser modificados por leis. É o que o conselho constitucional afirmou numa decisão de 26 de junho de 1969:

"Considerando que, após um princípio geral de nosso direito, o silêncio da administração vale decisão de rejeição e que na espécie, não pode ser derrogado senão por uma decisão legislativa." "7o

E acentua Rivero:

"A decisão pode ser puramente tácita: quando a administração, recebendo um pedido, não responde num prazo de quatro meses, seu silêncio é normalmente interpretado como uma recusa, excepcionalmente, quando um texto preveja, como uma aceitação" "1

3) Para Roberto Dromi, a vontade pode ser expressa ou tácita. No primeiro caso, quando a conduta administrativa se exterioriza através da palavra oral ou escrita ou por símbolos ou signos. A vontade é tácita quando o silêncio administrativo, por expressa previsão do ordenamento jurídico, é considerado ato administrativo. $O$ ordenamento jurídico argentino em geral prescreve que o silêncio administrativo deve considerar-se negativamente, ou seja, que se haja denegado o pedido do administrado (denegação tácita).

Segundo o autor argentino, silêncio é presunção de vontade e também substituição de vontade para não deixar desamparado o reclamante. O sentido da inércia administrativa, equivale, para efeitos processuais, à denegação. ${ }^{72}$

4) O silêncio "negativo" é uma ficção legal de efeitos exclusivamente processuais, ao permitir ao administrado recorrer; não é ato administrativo, mas a ausência de um ato substitui o ato expresso, mas só a estes concretos fins e em benefício do particular. Esta a lição de Garcia de Enterría ${ }^{73}$, a qual se afeiçoa a de André Gonçalves Pereira. Contudo, o mesmo autor espanhol, quanto ao silêncio "positivo", entende corresponder a um "verdadeiro ato administrativo, equivalente a essa autorização ou aprovação às que substitui." 74

5) Themístocles Brandão Cavalcanti distingue a inércia da administração do silêncio na decisão, provocada por terceiros. No primeiro caso, pode o silêncio, a inércia, a falta de iniciativa importar na decadência do direito. Assim, a falta do

70 "Considérant que, d'aprés un principe général de notre droit, le silence gardé par l'administration vaut décision du rejet et qu'en l'espèce, il ne peut y être dérogé que par une décision législative" (André de Laubadère, "Traité de Droit Administratif”, Tome I, p. 633, tradução do autor)

71 “La décision peut d'ailleurs être purement tacite: lorsque l'administration, saisie d'une demande, n'y a pas répondu dans um délai de quatre mois, son silence est normalement interpreté comme um refus, exceptionnellement, lorsqu'um texte le prévoit, comme une acceptation". ("Droit Administratif", p. 88 , tradução do autor).

72 “Derecho Admininistrativo", p. 248. Conforme Agustín Gordillo a denegação "tem o valor conferido pela norma, de declaraçāo de vontade suficiente para interpor os recursos administrativos e judiciais pertinentes, equiparando-se aos atos da funçāo administrativa". (ob. cit., Tomo III, Cap. III-5)

73 "Curso de Direito Administrativo", p. 517.

74 Idem, p. 522. 
exercício do poder de polícia, de medidas coercitivas de restrições ao exercício de direito, quanto à maneira e à forma de praticá-los. implicará, tacitamente, no consentimento. Mas, a falta de despacho de um pedido, em um requerimento, não pode ser considerada assentimento tácito, reconhecimento implícito da legitimidade da pretensão de terceiros, perante o Estado ou a administração. ${ }^{75}$

$\mathrm{O}$ saudoso jurista brasileiro, seguindo Velasco ${ }^{76}$, formula as seguintes regras:

" 1 o $\mathrm{O}$ silêncio tem que estar previsto ou interpretado na lei. Sua significação própria não deriva de atos ou de omissões, a menos que lhes tenha outorgado a lei uma significação determinada.

$2^{2}$ Omitir um ato de natureza discricionária não tem significação jurídica alguma; é um ato indiferente ao direito.

$3^{2}$ Por conseguinte, a noção do silêncio administrativo é uma noção empírica, que afasta toda regra abstrata.

$4^{\circ}$ Manifesta-se diante da faculdade-poder, visto como, diante da faculdade-dever, deve-se considerar mera abstração. Nesse caso do silêncio, a administração pode falar, mas não tem o dever de fazê-ło. Caracteriza-se, também, porque somente aparece nos atos requeridos, e não nos espontâneos, que o próprio conceito elimina." 77

6) Osvaldo Aranha Bandeira de Mello ${ }^{78}$ menciona, entre as causas do "ato administrativo", a "causa agente ou eficiente instrumental", ou seja, o meio pelo qual a manifestação de vontade se revela, o que lhe dá aparência, podendo ser, quanto à estrutura, "expressa e tácita". Interessa-nos apenas esta, em face do tema proposto.

Conforme o autor, a forma tácita resulta indiretamente com referência a dado assunto, por intermédio de (a) ato positivo, jurídico ou material (o particular requer a devolução de determinado imóvel, sob alegação de que está indevidamente em poder da administração pública, por lhe pertencer; mas, a administração, em vez de deferir ou não o pedido, determina que no local se construa uma escola pública de modo "tácito", ficou indeferido o pedido); e (b) ato negativo, o silêncio (se a lei lhe der esse alcance, de recusa ou de um consentimento).

$\mathrm{O}$ autor ressalta o caso de ato positivo, jurídico ou material, vale dizer, a manifestação tácita, que equivale a ato jurídico-administrativo, deduzida de "fact concludentia". Estabelece, ainda, regras importantes:

a) só se tolera se decorre de "comportamento querido pela administração pública" cuja consequiência tenha previsto; não pode provir de inação inconsciente. A manifestação tácita equivale a uma declaração expressa que deixou de existir, e, através daquela esta se deduz, quanto aos efeitos de direito. Logo, a pessoa que ocupa, durante vários anos, sem qualquer ato administrativo, imóvel público, de uso público, não pode ser considerada "concessionária de uso"; quando muito, seria

75 ob. cit., p. 206.

76 "El acto administrativo", pág. 206.

77 "Tratado de Direito Administrativo", Vol. I, p. 207.

78 ob. cit., p. 496-504. 
apenas "permissionária de uso", título precário. gratuito e revogável a qualquer tempo.

b) as manifestações tácitas de vontade, de regra, são as pertinentes a situações que configuram "atos implícitos", como resultantes de "outros atos expressos que os pressupõem". Se a autoridade decidisse vender bem público já materialmente desafetado, mas sem a prévia declaração formal de desafetação, pois o ato jurídico de decisão da venda implica, necessariamente, de modo indireto, na declaração formal dessa desafetação.

c) deve emanar do "mesmo órgão competente para editar o ato". Não se violam as "regras de fundo e de forma exterior". Se o ato exigir trâmite prévio ou maioria especial, e o comportamento do qual se pretende defluir manifestação implícita se perfaz independentemente dessas exigências, não se pode concluir tenha havido manifestação de vontade implícita - "esta não pode existir com desrespeito a requisitos formais exteriores obrigatórios, desrespeito a formalidades legais."79

Quanto ao silêncio, uma das "manifestações tácitas da vontade", equivalente a ato administrativo, pode decorrer da "inação" (a qual gera manifestação de vontade) e jamais da "inércia" (esta gera apenas a decadência do direito). Em seguida, o autor elenca situaçōes possíveis:

a) a lei pode atribuir ao silêncio efeito jurídico (assentimento ou recusa), após o decurso de certo prazo. Pode declarar que, não despachado qualquer requerimento no prazo de 30 dias, deve haver-se como indeferido.

b) outras vezes, sem expressamente afirmar o efeito positivo ou negativo do silêncio, lhe emprestar, indiretamente, um determinado significado. A lei pode declarar que, decorrido o prazo probatório, sem manifestação em contrário dos órgãos administrativos, o funcionário nomeado para cargo público efetivo adquire tal situação jurídica. ${ }^{80}$

c) a lei não diz como interpretar-se o silêncio da administração pública. Então, dois casos podem apresentar-se: c. l) se a lei a obriga a praticar determinado ato em certo prazo, e decorrido este, ela se mantém indiferente, pode o interessado notificá-la para, em prazo que lhe marcará - nunca inferior ao já esgotado e legalmente prefixado - se pronuncie a respeito, sob pena de haver-se como "negativa sua manifestação"; c. 2) se a lei não a obriga a praticar o ato, em prazo prefixado, é possível seja notificada, com prazo razoável, pelo interessado se essa manifestação é condição para que ele possa utilizar-se de outras medidas em defesa dos seus direitos, e recorrer a outras autoridades administrativas ou judiciais.

d) quanto aos atos administrativos de controle ${ }^{x /}$ : (a) na falta de dispositivo legal, marcando prazo para manifestação da administração, não há possibilidade de inter-

79 ob. cit., p. 496-504.

80 Hoje, em face do disposto no artigo 41, parágrafo 4ํㅡ da Constituição Federal de 1988, a lei nāo poderá atribuir tal efeito ao silêncio da administração.

81 "Atos controladores são os que confirmam ou infirmam a legitimidade dos atos do procedimento ou a oportunidade da decisão final" (Celso Antônio Bandeira de Mello, ob. cit., p. 318). Por exemplo, a homologação ou a nulidade do procedimento licitatório, realizado por autoridade superior. 
pretação de silêncio. para considerá-lo de recusa ou aceitação do ato controlado: (b) se o prazo existir e decorrer sem manifestação, fica caduco o seu direito de contraste na hipótese - o silêncio terá efeito positivo; o ato administrativo se torna eficaz, a partir daí.

e) quanto aos atos administrativos espontâneos, o silêncio não gera consequiências, exceto a responsabilidade da administração pública: (a) se há prazo marcado, a falta de decisão acarreta a responsabilidade civil perante o Judiciário, pelos danos; (b) se não há, apenas a responsabilidade política, pela má administração. ${ }^{82}$

f) com referências aos atos administrativos provocados, (a) se há prazo marcado, ou se acham sujeitos a condição a favor dos particulares, a falta de decisão, após o seu decurso, torna a pretensão indeferida ou caduca; (b) se inexiste prazo, mas foi cominado, os seus efeitos jurídicos serão apreciados pelo Judiciário.

7) As consequiências da omissão do Poder Público, acima relatadas pelo insigne mestre paulista, são perfeitamente aceitas pela razoabilidade de suas conclusões, na medida em que não há lei alguma atribuindo ao silêncio da administração determinado efeito, negativo ou positivo. Apenas a lei federal $\mathrm{n}^{\mathbf{0}} 9.784$, de 29 de janeiro de 199, que regula o processo administrativo no âmbito da Administração Pública Federal, dispõe nos artigos 48 e 49:

Art. 48. A Administração tem o dever de explicitamente emitir decisão nos processos administrativos e sobre solicitações ou reclamações, em matéria de sua competência.

Art. 49. Concluída a instrução de processo administrativo, a Administração tem o prazo de até trinta dias para decidir, salvo prorrogação por igual período expressamente motivada.

De fato, cabe à Administração Pública motivar os atos administrativos; para isso, deve editá-los, expressamente, indicando os fatos em que se baseou, a regra de direito pertinente ao ato e a relação de adequação entre os fatos (motivo) e o conteúdo do ato. Não lhe compete omitir-se aos pedidos feitos pelos administrados, mesmo porque a norma constitucional, descrita no artigo $5^{\circ}$, inciso XXXIII e inciso XXXIV, letras " a" e "b" ${ }^{83}$ determina a obrigatoriedade da manifestação estatal, ante o pedido

82 Após a Constituição Federal de 1988, temos o artigo 5², LXXI, segundo o qual "conceder-se-á mandado de injunção sempre que a falta de norma regulamentadora torne inviável o exercício dos direitos e liberdades constitucionais e das prerrogativas inerentes à nacionalidade, à soberania, e à cidadania."

83 Art. 5" Todos são iguais perante a lei, sem distinção de qualquer natureza, garantindo-se aos brasileiros e aos estrangeiros residentes no País a inviolabilidade do direito à vida, à liberdade, à igualdade, à segurança e à propriedade, nos termos seguintes: XXXIII - todos têm direito a receber dos órgãos públicos informações de seu interesse particular, ou de interesse coletivo ou geral, que serão prestadas no prazo da lei, sob pena de responsabilidade, ressalvadas aquelas cujo sigilo seja imprescindível à segurança da sociedade e do Estado; XXXIV — são a todos assegurados, independentemente do pagamento de taxas: a) o direito de petição aos Poderes Públicos em defesa de direito ou contra ilegalidade ou abuso de poder; b) a obtenção de certidões em repartições públicas, para defesa de direitos e esclarecimento de situações de interesse pessoal; 
do indivíduo. Logo. todo pedido do administrado deverá ser decidido. As omissões estatais não podem corresponder a atos administrativos.

Aliás, o Superior Tribunal de Justiça teve oportunidade de decidir que somente a manifestação da Administração marca o início do prazo prescricional:

"Administrativo - Silêncio da Administração - Prazo Prescricional.

A teoria do silêncio eloqüente é incompativel com o imperativo da motivação dos atos administrativos.

Somente a manifestação da Administração pode marca o início do prazo prescricional" ${ }^{8.4}$

O julgado acima refere-se a policial militar, autor da ação, que pediu ao Poder Público sua promoção, invocando permissivo contido em lei estadual. Embora o requerente não tenha obtido a resposta, outros policiais militares; mediante pedidos deduzidos perante o Poder Público, obtiveram o deferimento e passaram a gozar da nova situação jurídica, decorrente da promoção efetivada. Ou seja, enquanto o pedido do autor não obteve resposta, as pretensões dos seus homólogos foram deferidas.

Alegava-se, na ação, o prazo prescricional de 05 anos, porquanto a promoção a outros requerentes, que pleiteavam idêntico direito, importava ato inequívoco.

Acentuou o ilustre relator:

"A importância dos motivos na formação e no controle do ato administrativo é reconhecida entre nós. Tanto que o Legislador inseriu entre as causas de nulidade dos atos administrativos, a inexistência de motivos (Lei $\mathrm{n}^{\circ} 4.717$, de 20-6-65 art.2‥-d).

Ato cujos motivos não estejam ao alcance de seus destinatários é ato nulo. Se assim ocorre, não há como aplicar a teoria do silêncio eloquiente aos atos administrativos.

Muito menos, quando se trata de resposta devida pelo Estado às petições que lhe são dirigidas.

O direito de petição, inserido entre as garantias fundamentais do art. $5^{\circ}$ da nossa Constituição Federal, tem como corolário o direito à resposta.

Não houvesse a obrigação de responder, o direito de petição mereceria integrar $o$ acervo das solenes inutilidades.

Enquanto não responde ao requerimento, a Administração está em mora.

O silêncio traduz inadimplência, não resposta implícita.

(...)

Quando há indeferimento explícito, o marco inicial será a intimação do ato denegatório ao interessado.

Ora, se não existe ato, não haverá como estabelecer o início do prazo prescricional.

É impossível, sem abdicar da seriedade, admitir que o Estado se dirija a quem lhe dirigiu uma petição, para lhe comunicar que ao apreciar o pedido, decidiu permanecer em silêncio."

REsp 16.284 - Rel. Min. Gomes de Barros — DJU 23.3.92, p. 03447. 
Aliás, "tratando-se de ato omissivo. não há que falar em decadência do direito a impetração da segurança" ${ }^{*}$; e que "a falta de resposta a requerimento que the foi dirigido, seja concedendo ou negando o pedido em prazo razoável, caracteriza a omissão da autoridade apontada como coatora" "*6; "mero silêncio da Administração não constitui ato administrativo, e sua inércia, no caso, não ofende direito subjetivo do recorrente" ${ }^{87}$; "o interregno de seis meses entre a instalação do inquérito para apuração de falta grave e o ato demissório não se constitui perdão tácito" "88; " a falta de imediata punição ao discente pela demora na apuração dos fatos não implica perdão tático" ${ }^{8 y}$

8) Diante disso, estamos com o jurista Celso Antônio Bandeira de Mello, para quem "o silêncio não é ato jurídico". determinado efeito ao silêncio: o de conceder ou negar. Este efeito "resultará do fato da omissão, como imputação legal, e não de algum presumido ato, razão por que é de rejeitar a posição dos que consideram ter aí existido um "ato tácito" ${ }^{11}$ Isso porque o silêncio é um fato administrativo, e não uma declaração estatal. Remetemos aos comentários feitos anteriormente, quando fizemos a distinção entre ato administrativo e fato administrativo.

Finalmente, quando se cuidar de ato administrativo discricionário ${ }^{92}$, e a lei não prever o efeito da omissão estatal, ante o pedido do particular, se este ingressar no Judiciário, deverá fazê-lo apenas para que a autoridade administrativa se manifeste em prazo razoável, sob pena de multa diária; ou, a nosso ver, alternativamente, sob pena de reconhecimento do indeferimento da pretensão. Com efeito, não compete ao juiz fazer as vezes do administrador, substituindo-lhe a vontade, valorando os fatos como se fosse a autoridade administrativa. De outro lado, o indeferimento da pretensão, nos termos indicados, reconhecido pelo magistrado, pela inércia da autoridade administrativa, não significa invadir competência alheia, no caso a do Poder Executivo, mas de permitir ao administrado socorrer-se das vias recursais perante a Administração Pública, ou de novamente ingressar no Judiciário, pleiteando seus direitos.

No caso de ato administrativo vinculado ${ }^{93}$, ao contrário, se a lei não trouxer os efeitos legais diante da omissão do agente administrativo, o particular poderá solicitar diretamente ao juiz sua pretensão não atendida pela Administração. Isso porque, no

85 STJ, MS 14708, Rel. Min. Hélio Mosimann, DJU 23.11.92, p. 21829.

86 STJ, MS 17711, Rel. Min. Peçanha Martins, DJU 24.2.92, p.01847.

87 TRT 1 ㄹ, Ap. Civ. Ac. 0121155-6, Rel. Juíza Orlanda Ferreira, DJU 27.11.89.

88 TRF 4-R, RO 0419293-5, k Rel. Juiz Teori Albino Zavascki, DJU 17.10.90, p. 024356.

89 TRF 5 R, Ap. MS 00500326-7, Rel. Juiz Castro Meira, DJU 02.12.89.

90 ob. cit., p. 293.

91 Idem, p. 294.

92 Ato administrativo editado na competência discricionária é aquele no qual o agente atua mediante critérios de conveniência e oportunidade, valorando os falos. com certa dose de subjetivismo.

93 Ato administrativo editado na competência vinculada é aquele no qual o agente atua sem margem de liberdade para decidir, pois a lei indicou o único comportamento possível. 
próprio conceito de ato editado na competência vinculada, não há margem de liberdade ao administrador, critérios de conveniência ou oportunidade. Logo, o juiz poderá, simplesmente verificando o caso concreto, deferir ou indeferir o pedido do autor da ação. Se o administrado solicita à Administração licença para edificar, e este fica silente por prazo razoável, aquele poderá pedir ao juiz a determinação para que o agente público expeça o ato administrativo (licença), sob pena de responsabilidade penal, administrativa e civil.

Mesmo vencido o prazo legal para se pronunciar, pode sempre a Administração Pública se manifestar, exceto, segundo pensamos, no caso de ato administrativo editado na competência vinculada e tendo sido deferido o pedido pelo juiz, isto é, tendo este acolhido a pretensão do particular (ex: aposentadoria por tempo de serviço e de contribuição). Neste caso, não pode mais a Administração manifestar-se.

$\mathrm{Na}$ hipótese de ato administrativo discricionário, se o magistrado reconhecer, na ação ajuizada, o "indeferimento" da pretensão por parte da Administração, esta, ainda assim, poderá manifestar-se em sentido contrário, vale dizer, terá condições de aquilatar os fatos, sopesá-los e deferir o pedido do particular. Evidentemente, poderá mesmo indeferi-lo, motivadamente. ${ }^{94}$

\section{B) Conclusões}

Ao cabo da explanação referida, alinhamos, sucintamente, as seguintes conclusões:

a) A função administrativa é a atividade estatal realizada por agentes do Poder Executivo, como regra, do Poder Legislativo e do Judiciário, excepcionalmente, mediante atos e comportamentos complementares da lei, para dar-lhe perfeita aplicação, na conformidade de um regime hierárquico, submetidos a controle jurisdicional.

b) $\mathrm{O}$ ato administrativo é toda declaração unilateral do Estado, ou de quem lhe faça as vezes, em complemento da lei, editada no exercício da função administrativa, podendo ter efeitos jurídicos diretos ou indiretos, concretos ou abstratos, gerais ou individuais, excetuados os atos regidos pelo Direito Privado e os atos políticos ou de governo.

c) O fato jurídico-administrativo é um acontecimento da natureza ou humano, voluntário ou involuntário, o qual o ordenamento atribui efeitos jurídicos; é ato material, nada pronuncia, apenas ocorre.

d) $\mathrm{O}$ ato administrativo tácito e o ato administrativo implícito (em suma: o silêncio da Administração) não são declarações; constituem fatos jurídicos, e dessa, forma, não estão submetidos ao regime próprio dos atos administrativos. Não existem

94 Para Themístocles Brandão Cavalcanti, perante nosso direito, "o único recurso cabivel [da mora da Administraçāo] é o judicial, por meio ou da propositura da ação competente, ou de simples notificação, que trazem sempre como conseqüência, nos termos do Código Civil, a suspensão do curso da prescrição." (ob. cit., p. 209). 
atos tácitos e implícitos. pois o conceito de ato pressupõe uma declaração. uma manifestação do agente público, o que não ocorre com o fato jurídico-administrativo.

e) À falta de texto legal, como o nosso, atribuindo ao silêncio estatal determinado efeito jurídico, a princípio, não se pode concluir algo, quanto aos direitos e sobretudo aos deveres dos administrados, exceto no primeiro caso (direitos), na hipótese de reconhecimento judicial de indeferimento do pedido do administrado, ante a omissão do agente público, na competência discricionária; se for competência vinculada, o próprio juiz poderá suprir a omissão, determinando ao Poder Público o cumprimento do que foi decidido, a entrega da pretensão pedida pela parte. 